\title{
Froth and Bubble: The Inconsistency of Paul Krugman's Macroeconomic Analysis
}

\author{
DON HARDING AND JAN LIBICH ${ }^{1}$
}

Consistency is one of the touchstones used to evaluate not only arguments but also the people that put forward the arguments. In assessing the person advocating an argument, it is natural to look for coherence over time in their arguments and, secondly, whether the person offers a convincing explanation for a change of view. We apply this framework to evaluate some of Paul Krugman's macroeconomic analysis.

\section{Froth and Bubble in 2002}

In the New York Times in August 2002, Paul Krugman writes: 'To fight this recession the Fed needs more than a snapback; it needs soaring household spending to offset moribund business investment. And to do that, as Paul McCulley of Pimco put it, Alan Greenspan needs to create a housing bubble to replace the Nasdaq bubble' (Krugman 2002).

In blog and newspaper pieces around that time Krugman is encouraging the Federal Reserve to achieve such stimulus through looser monetary policy. For example, he argues: 'It's still not clear that Mr. Greenspan has caught up with the curve - let's have at least one more rate cut, please.' (Krugman 2001). Yet half a decade later he argues: 'If there are two guys that I blame for this crisis it would be, in order, Alan Greenspan and Phil Gramm.' (Krugman 2008a)

It is reasonable enough to change one's mind. But to change one's mind without explanation, and to compound the aggravation by damning those who implemented the very policy that one favoured at the time, is extraordinary.

1 La Trobe University, J.Libich@latrobe.edu.au. 
Not content to leave this well alone Krugman disingenuously explains in regard to his 2002 piece quoted above, that: 'It wasn't a piece of policy advocacy, it was just economic analysis.' (Krugman 2009a)

\section{Which Paul Krugman Was Right About Policy in 2002?}

The recession of 2001 was one of the shortest (March-November) and mildest in US history. The unemployment rate rose from the December 2000 low of 3.9 per cent to 5.7 per cent a year later; a rate it roughly held throughout 2002. Employment performed similarly well. Inflation reached its low of 1.1 per cent in January and February 2002, and then started rising steadily (with a small temporary dip in June/July 2002). GDP actually grew in the first and second quarters of 2002 by 1.6 per cent and 1.5 per cent (annual rate), respectively. ${ }^{2}$

There are many more things that one might want to take into account but even so it is hard to find evidence of sufficient importance to justify Krugman's extremely pessimistic assessment of the situation in mid-2002.

Moreover, there are well-respected alternative views of policy in that recession. For example, according to Taylor's (2007) estimates, the traditional Taylor rule (that had described the Federal Reserve's behaviour quite well up until that time) prescribed increases of the Fed Funds rate to start already at the end2001 , and to continue at a steady pace to reach 4 per cent at the end of 2003 (as opposed to the rate of 1 per cent observed at the time). ${ }^{3}$

There have been some revisions in the original data available to policymakers in real time, but these do not change the overall picture: in August 2002 there was little reason to panic and call for dramatic policy measures, as Paul Krugman did. This is especially true considering the fact that the world economy (except perhaps for Western Europe) was performing fairly well, and that the expansionary effects of the 2000-01 interest-rate cuts were still largely in the pipeline.

\footnotetext{
2 Note that the level of GDP never recorded a sustained decline, and thus identifying this period of time as recession was not uncontroversial. Furthermore, the NBER dating committee indicated that in the absence of the September 11 terrorist attacks: '...it is possible that the decline in the economy would have been too mild to qualify as a recession' (see Hall et al. 2001).

3 Bernanke (2010) disputed Taylor's conclusions, arguing that monetary policy was not excessively expansionary during the early 2000s if one uses contemporaneous (not forecast) values of inflation and output. Papell (2010), however, shows that Bernanke's results arise from using two different measures of inflation (headline versus core), rather than the contemporaneous versus forecast inflation distinction.
} 


\section{Deficit Trouble in 2003}

By 2003 debt and deficits were the issue. In March 2003 Krugman writes:

But what's really scary — what makes a fixed-rate mortgage seem like such a good idea - is the looming threat to the federal government's solvency.'

That may sound alarmist: right now the deficit, while huge in absolute terms, is only 2 - make that 3, O.K., maybe 4 - per cent of GDP. But that misses the point.

Think of the federal government as a gigantic insurance company (with a sideline business in national defense and homeland security), which does its accounting on a cash basis, only counting premiums and payouts as they go in and out the door. An insurance company with cash accounting...is an accident waiting to happen.

So says the Treasury under-secretary Peter Fisher; his point is that because of the future liabilities of Social Security and Medicare, the true budget picture is much worse than the conventional deficit numbers suggest.

Of course, Mr. Fisher isn't allowed to draw the obvious implication: that his boss's push for big permanent tax cuts is completely crazy. But the conclusion is inescapable. Without the Bush tax cuts, it would have been difficult to cope with the fiscal implications of an ageing population. With those tax cuts, the task is simply impossible. The accident - the fiscal train wreck — is already under way. (Krugman 2003)

This is pretty much a mainstream view that many economists would understand. It's a point of view that John Maynard Keynes, who unlike many of his followers was not a proponent of over-reliance on deficit spending or tax cuts, would agree with. ${ }^{4}$ But the issue again is the consistency of Krugman's arguments. As Lee (2009) observes:

The problem is that everything Mr. Krugman now writes entirely contradicts his 2003 article, despite the fact that every fundamental problem the economy faced six years ago is now much worse. Mr. Krugman has no issues with Barack Obama and Ben Bernanke committing the same atrocities the previous administration committed. President Obama has ramped up every budget, including the military budget,

4 Many modern-day Keynesians gloss over the fact that in How to Pay for the War, published in 1940, Keynes argues for higher taxation to fund the spending. 
while Bernanke runs the presses faster than Greenspan ever did. Mr. Krugman has consistently stated throughout 2009/2010 that there is no danger of interest rates rising in the future and that the budget deficit is not disastrous by comparison to 1940s United States and 1990s Japan.

\section{The Twist and Turns of Economic History}

Nobody can be like Keynes and no book can be like the General Theory. It was a book that solved the problem that nearly brought down Western civilization.' (Krugman 2008b)

There is no doubt that Keynes was one of the most influential economists of the twentieth century, but the claim that he 'solved the problem that nearly brought down Western civilization' is not supported by the evidence.

The Means to Prosperity, published in 1933, recommended increased public spending, though not necessarily deficits, as a means to reduce unemployment.

${ }^{5}$ But there is little evidence that it had a direct effect on macroeconomic policy during the Great Depression. Skidelsky (2003), Keynes' biographer, reports that Keynes' policy suggestions only began to influence US economic policy after 1939, by which time the depression had ended.

It is true that the Swedes did employ some Keynesian ideas in the Great Depression (Skidelsky 2003). It is also true that German public spending in the Depression had some of the positive economic effects foreseen by Keynes. But, Keynes never claimed either of these examples as support for his ideas. Sweden was too small and the other German policies too abhorrent.

\section{Truth and Beauty}

So what are the lessons that Paul Krugman has learnt from the global financial crisis of 2007-09? Among others, in his highly publicised article (Krugman 2009 b) he expressed the view that the state of macro 'is not good'. His argument is that the profession has mistaken 'beauty for truth' in terms of hi-tech models that do not reflect the economic reality.

Many others have dissected his arguments on this (see, for example, Cochrane 2009 or Kocherlakota 2009). We have documented the changing state and consistency

5 As quoted in his Collected Works (volume 21, 94), Keynes stated: 'I am sure the Premiers' Plan last year saved the economic structure of Australia', referring to the Plan of April/May 1931 which recommended a reduction in the Commonwealth deficit from $£ 39$ million to $£ 11$ million, to be secured by a $£ 13$ million reduction in outlays, $£ 12$ million increase in taxes, and $£ 3$ million from reduced interest. 
of Paul Krugman's macroeconomic policy analysis. ${ }^{6}$ The contrast between his assessment of 2002/2003 and 2008/2009 is so large and the justification for the changed view so ephemeral that we feel his policy recommendations no longer have the required consistency and coherency. Rather than being the substance that nourishes public debate they seem to conceal the substance.

\section{References}

Bernanke, B. 2010, 'Monetary Policy and the Housing Bubble', Speech at the AEA meetings. Available at: www.federalreserve.gov/newsevents/speech/ bernanke20100103a.htm.

Cochrane, J. 2009, 'How did Paul Krugman get it so Wrong?' (blog post). Available at: http://modeledbehavior.com/2009/09/11/john-cochraneresponds-to-paul-krugman-full-text/.

Hall, R., Feldstein, M., Bernanke, B., Frankel, J., Gordon, R. and Zarnowitz, V. 2001, 'The Business-Cycle Peak of March 2001'. Available at: http://www. nber.org/cycles/november2001.

Keynes, J. M. 1933, The Means to Prosperity, London: Macmillan.

Keynes, J. M. 1940, How to pay for the war: a radical plan for the Chancellor of the Exchequer, London: Macmillan.

Kocherlakota, N. 2009, 'Some Thoughts on the State of Macro' (blog post). Available at: http://braddelong.posterous.com/narayana-kocherlakota-somethoughts-on-modern.

Krugman, P. 2001, 'Dodging the Bullet', The New York Times, 5 February, Available at: http://www.pkarchive.org/column/5201.html.

Krugman, P. 2002, 'Dubya's Double Dip?' The New York Times, 2 August, Available at: http://www.nytimes.com/2002/08/02/opinion/dubya-s-doubledip.html.

Krugman, P. 2003, 'A Fiscal Train Wreck', The New York Times, 11 March, Available at: http://www.nytimes.com/2003/03/11/opinion/11KRUG.html.

Krugman, P. 2008a, Interview in Gregory One on One (video), 22 September, Available at: http://www.youtube.com/watch?v=YwqcLbZJ4HA.

6 This does not in any way detract from the importance of Krugman's contributions to new trade theory for which he was awarded the Economics Nobel Prize. 
Krugman, P. 2008b, Paul Krugman talking about Keynes' General Theory (video), 30 June, Available at: www.youtube.com/watch?v=CVHWlnbJsC4.

Krugman, P. 2009a, 'And I was on the grassy knoll, too' (blog post). Available at: http://krugman.blogs.nytimes.com/2009/06/17/and-i-was-on-the-grassyknoll-too.

Krugman, P. 2009b, 'How did Economists Get it so Wrong?', The New York Times, 2 September, Available at: http://www.nytimes.com/2009/09/06/ magazine/06Economic-t.html?_r=1\&_r.

Lee, B. 2009, 'Paul Krugman's Identity Crisis' (blog post), 25 September. Available at: http://mises.org/story/3691.

Papell, D. 2010, 'Bernanke on the Taylor Rule' (blog post). Available at: http:// www.econbrowser.com/archives/2010/01/guest_contribut_6.html.

Skidelsky, R. 2003, John Maynard Keynes: 1883-1946: Economist, Philosopher, Statesman, Pan MacMillan Ltd.

Taylor, J. 2007, 'Housing and Monetary Policy', Proceedings, Federal Reserve Bank of Kansas City: 463-76. 